\title{
ABOUT THE METHODOLOGY OF PREPARATION OF BASKETBALL PLAYERS FOR THE GAME 3 x 3 BASKETBALL
}

\author{
L. Petrov*, M. Bonev \\ Theory and Methodology of Physical Education Department, Pedagogical Faculty, \\ St. Ciril and St. Methodius University of Veliko Tarnovo, Veliko Tarnovo, Bulgaria
}

\begin{abstract}
PURPOSE: In the preparation for competitions in $3 \times 3$ basketball some peculiarities in technical and tactical terms are observed.

METHODS: In the study we used content analysis and sports pedagogical observation.

RESULTS: Our observations showed that in attack the players are mainly looking for a pass from a teammate, fast shooting, mainly from the area behind the arc, inclusion in the fight for the ball bounced from the basket and a sharp transition to defence if the shooting is not successful. Interactions are short, often involving a pass, intersection or shelter, and long-range shooting. The main focus remains the individual game $1 / 1$.

CONCLUSIONS: Individual technical and tactical training and aggression are the factors that decide the success of the competitions. In the preparation for $3 \times 3$ basketball competitions to focus on:

- The opening when passing between the players in case of aggressive defence;

- Game 1/1;

- Shooting behind the arc;

- Pick and roll.
\end{abstract}

Key words: $3 x 3$ basketball, methodology, technical and tactical analysis

\section{INTRODUCTION}

$3 \times 3$ basketball is a relatively new competitive game and although it is based on traditional basketball, there are many differences that affect the technical and tactical training of athletes. The first official participation of athletes in this discipline will be at the Olympic Games in Tokyo in 2021. 3x3 basketball is played on one basket, and the rules of FIBA (International Basketball Federation) require duration of one match of 10 minutes, or up to 21 points scored. The team includes four players, three on the field and one in reserve. Unlike traditional basketball, the players themselves determine the shifts and breaks without the intervention of a coach. According to Stavrev (1), the

\footnotetext{
*Correspondence to: Lyudmil Petrov, St. Ciril and st. Methodius University of Veliko Tarnovo,

Bulgaria 5000 Veliko Tarnovo, 2 Teodosi

Tarnovski str., Pedagogical Faculty, Theory and methodology of Physical Education Department, email: ludmilpetrov55@gmail.com; mobile: $+35987886362$
}

division of players into external and internal is quite conditional and predominantly loses its meaning. The attack time is limited to 12 seconds and therefore more but short-term attacks on the basket are performed. In an attack, a quick shot is needed, mainly from the area behind the arc, involvement in the fight for the ball bounced from the basket, a sharp transition to defence, if it is controlled by a player of the other team. In defence is very typical active play against the shooting striker and against the one who takes the ball to the line of the arc to put it into play. Interactions are short, most often involving passing and shooting from a long distance. According to our research, regarding the game $3 \times 3$ basketball (2), in a survey of basketball coaches and teachers of physical education and sports, the game "3 x 3 basketball" has been very actively promoted in recent years in Bulgaria. According to another study (3), "in technical-tactical basketball training, $40 \%$ of specialists in this sport believe that children aged 12-14 can successfully play $1 / 1$ in attack 
and defense, and $60 \%$ - no. In the tactical interactions $2 / 2,55 \%$ of the coaches give a positive assessment, and 45 - negative. These answers of the coaches prove that basketball training is a difficult and long process and achieving success at the age of 12-14 is not the most important condition in many years of training.

Other authors who have studied similar issues related to basketball methodology are Aleksieva, Stefanov, Spahiu (4), Bozhkov (5), Kirov (6), Mitreva (7), Nesterovski (8) and Petrov (9).

\section{METHODS}

In the study we used content analysis and sport pedagogical observation. The aim of the research is to study the ways of attacking the basket in $3 \times 3$ basketball competitions, in order to improve the most important of them in sports training.

\section{Tasks:}

1. Research of information sources. 2. Survey of athletes and coaches. 3. Sports observation of the finals of the world championship in this sport.

\section{RESULTS}

We conducted a sports observation at the Final Meeting of the World Championship 3x3 Basketball in 2016 between the teams of Serbia and the United States (men), and found the following:

- the first thing that players think of when they master the ball is to pass a teammate $(48 \%)$,

- the second is a $1 / 1$ game (28\%), - the third shooting in the basket with a bounce for the rainbow (22.64\%), - the fourth is double pass $(9.44 \%)$ and - finally - dribble and pick and roll (3.77\%) (Figure 1):

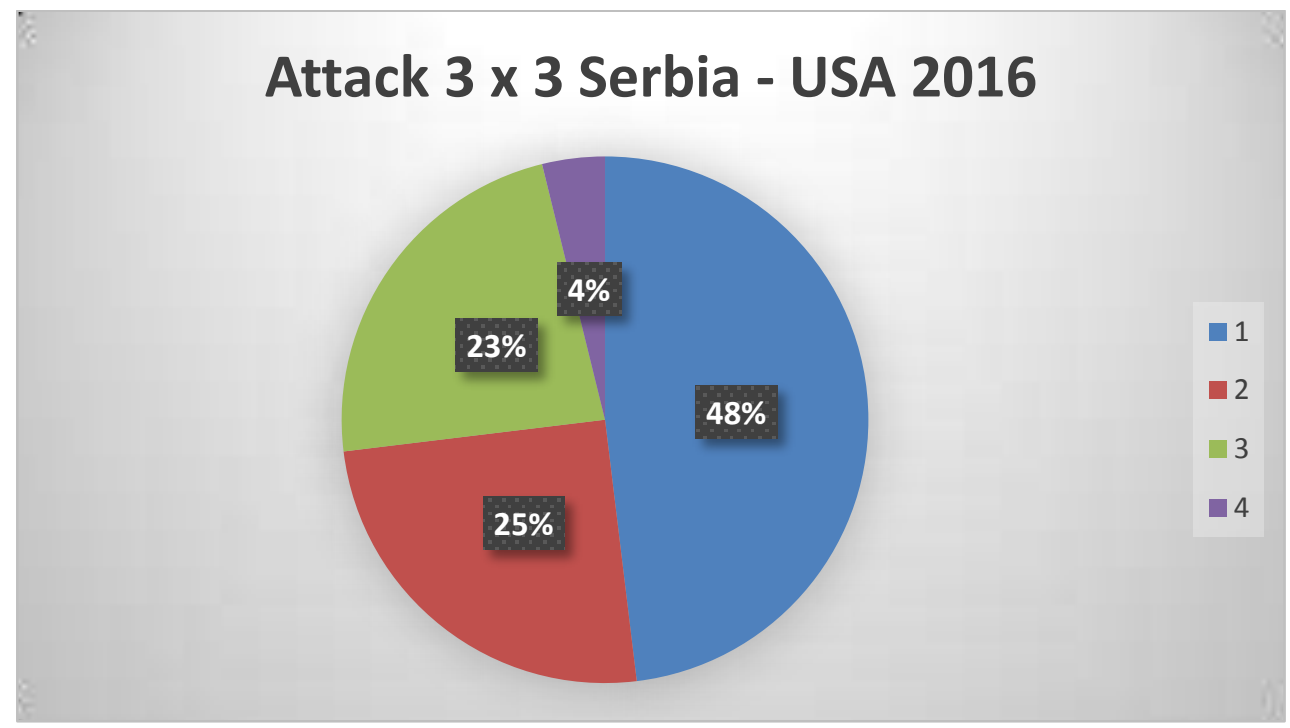

Figure 1. Interactions in attack total for the teams of Serbia and USA

In defence, often there is an aggressive counteraction when taking the ball behind the arc after a basket or a ball controlled under the basket before the attack starts. This often results in the ball being taken away before the attackers have taken it behind the arc.

We analysed the game in attack after a teammate's pass, as almost half of the attacks start this way. The most common action after a player receives a pass from a teammate is:

1. Shooting - 44\%;

2. Game $1 / 1-26 \%$;

3. Double pass $-15 \%$;

4. Pick and roll with a ball $-11 \%$;

5. Pick and roll without a ball - 4\%. Figure 2: 


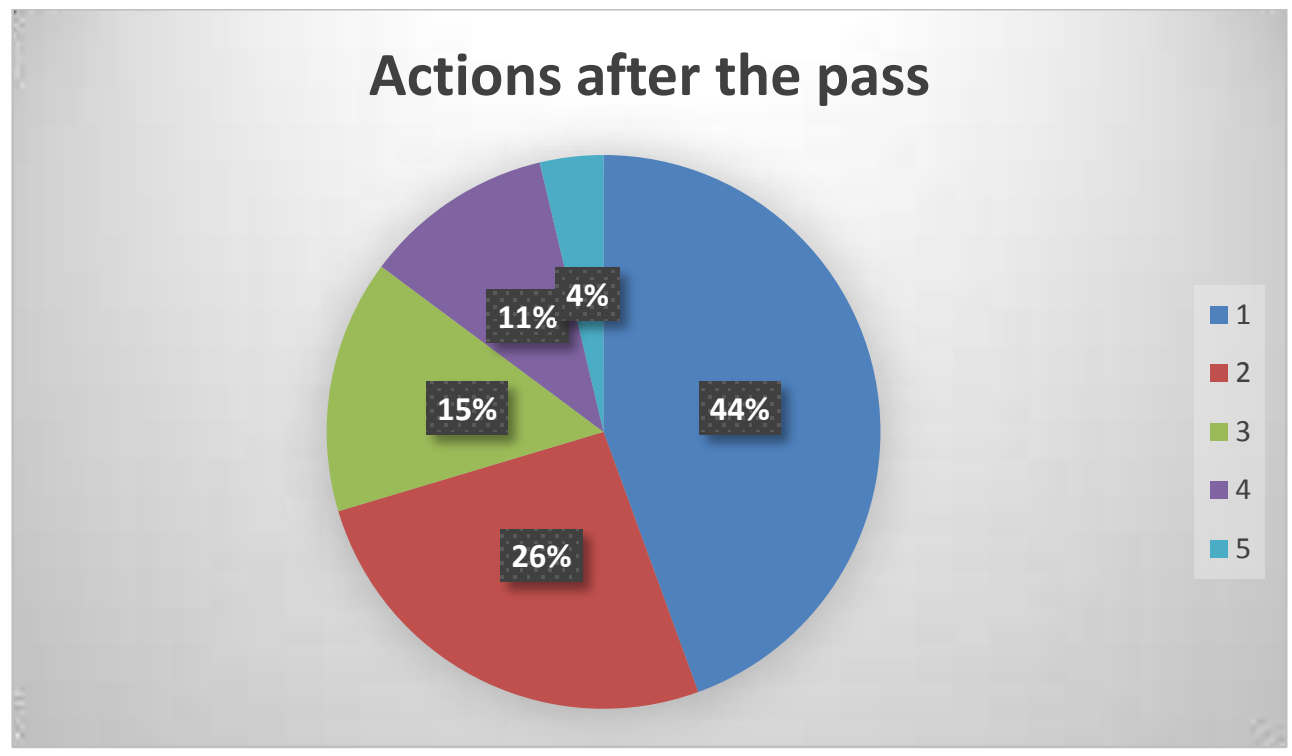

Figure 2. Tactical interactions after the pass

\section{CONCLUSIONS}

Individual technical and tactical training and aggression are the factors that decide the success of the competitions. In preparation for $3 \times 3$ basketball competitions the focus must be on:

- The opening when passing between the players in case of aggressive defence;

- Game 1/1;

- Shooting behind the arc;

- Pick and roll.

\section{REFERENCES}

1. Stavrev, S., Basketbol 3x3. Metodichesko rakovodstvo za studenti, prepodavateli $\mathrm{i}$ trenyori. Sofiya, I.K. na UNSS, Sofia, 2016.

2. Petrov, L. i kol., Sportove za rekreatsiya, I\&B, Veliko Tarnovo, 2010.

3. Petrov, L., Aleksieva, M., Kirov, D., Razvitie i upravlenie na sporta Basketbol 3 x 3, Sbornik dokladi ot „Mezhdunarodna nauchna konferentsiya „Pedagogicheskoto obrazovanie - traditsii i savremennost". Pedagogicheski fakultet, Velikotarnovski universitet „Sv.sv. Kiril i Metodiy“, Veliko Tarnovo, 2017.

4. Aleksieva, M., Stefanov, Sv., Spahiu, E., Anketno prouchvane otnosno myastoto na sporta $3 \times 3$ basketbol vav visshite uchilishta v Republika Albaniya, Sbornik ot
Edinadeseta mezhdunarodna nauchna konferentsiya ,Fizicheskoto vazpitanie, sportat $i$ rekreatsiyata $v$ obrazovatelnata sistema“ - Sofiyski universitet „Sv. Kliment Ohridski“, Departament po sport, Universitetsko izdatelstvo „Sv. Kliment Ohridski““, Sofiya, 139 - 146, 2019.

5. Bozhkov, G., Model za sportna podgotovka na elitni basketbolistki, disertatsiya, Rusenski universitet „Angel Kanchev“, Ruse, 2015.

6. Kirov, D., Prouchvane na mnenieto na sportuvashtite „basketbol 3 × 3“. Spisanie Pedagogicheski almanah, 2: 189-195, 2018.

7. Mitreva, B., Metodika na obuchenie po basketbol 3 h 3 vav visshite uchilishta, disertatsiya, Sofiyski universitet, Sofiya, 2015.

8. Nesterovskiy, D., Basketbol - teoriya i metodika obucheniya, Akademiya, Moskva. www.academia-moscow.ru, 2010.

9. Petrov, L., Bonev, M., Prouchvane mnenieto na basketbolnite spetsialisti otnosno "3 x 3 basketbol" v stranata, Sbornik ot Mezhdunarodna nauchna konferentsiya, "Pedagogichesko obrazovanie - traditsii $i$ savremennost", Veliko Tarnovo, 56-61, 2018. 